\title{
Hiilidioksidilannoituksen vaikutus leikkoruusun viljelyn kannattavuuteen - tilamallitarkastelu
}

\author{
Pia Outa ${ }^{1)}$ ja Liisa Särkkä ${ }^{2)}$ \\ 1) MTT Taloustutkimus, Luutnantintie 13,00410 Helsinki,_pia.outa@mtt.fi \\ 2) MTT Puutarhatuotanto,Toivonlinnantie508,21500Piikkiö, liisa.sarkka@mtt.fi
}

\begin{abstract}
Johdanto
Leikkoruusu on merkittävin Suomessa viljeltävistä leikkokukista sekä tuotannon arvon että pinta-alan perusteella. Kasvihuonetuotannossa kasvuympäristön ja viljelyolojen hallinta on erityisen tärkeää kasvulle ja sadon muodostumiselle. Hiilidioksidi ja säteilyenergia ovat keskeiset, kasvua säätelevät tekijät kasvihuoneviljelyssä. Korkeilla valon intensiteeteillä, kuten kesällä tai voimakkaalla lisävalotuksella, hiilidioksidista tulee kasvua rajoittava minimitekijä. Hiilidioksidin lisäys on etenkin ruusun talviviljelyssä välttämätöntä. Ruusukasvustolle $\mathrm{CO}_{2}$-lannoitus tulisi antaa puhtaana hiilidioksidina taimirivien väliin asennetuista putkista, josta se pääsee nousemaan ylöspäin.
\end{abstract}

\section{Aineisto ja menetelmät}

MTT puutarhatuotannon yksikössä on tutkittu eri pitoisuuksilla annetun hiilidioksidilannoituksen vaikutusta leikkoruusun sadon määrään ja laatuun. Viljelykokeiden tulosten perusteella on MTT taloustutkimuksessa laadittu tuotantokustannuslaskelmat tilamallitarkasteluna. Tilamallilaskelmat on alun perin laadittu tuotantokustannusten seurantaan. Mallilaskelmien avulla voidaan kuitenkin tarkastella myös eri tuotantotapojen välisiä kustannus- ja kannattavuuseroja muokkaamalla malli kuvaamaan haluttua viljelytekniikka tai -tapaa.

$\mathrm{CO}_{2^{-}}$ruusun tuotantokustannuslaskelmat on laadittu esimerkkitilalle, jonka viljelypinta-ala on $5000 \mathrm{~m}^{2}$. Satotiedot, kasvinsuojelu, valotustunnit ja hiilidioksidin määrät ovat MTT puutarhatuotannon viljelykokeiden tietoja. Koejäseniä $\left(\mathrm{CO}_{2}\right.$-lannoitustasoja) ja siten myös tilamalleja on kolme; $700 \mathrm{ppm}, 400$ ppm, ja 0 ppm. Todellisuudessa ilman hiilidioksidipitoisuus osastoissa oli 680 ppm, 400 ppm ja 350 ppm. Viljelykokeissa oli kussakin koejäsenessä kaksi eri ruusulajiketta, Frisco ja Sacha. Laskelmissa käytettävät satotasot ovat näiden kahden lajikkeen keskiarvoja. Suurin sato saatiin viljelykokeissa korkeimmalla hiilidioksidipitoisuudella (kuva 1).

Laskelmissa on kustannuksissa käytetty vuoden 2000 hintatasoa. Tuotantopanosten hinnat on kysytty jälleenmyyjiltä sekä ammattiviljelmiltä. Kaikki tarvikkeiden hinnat ovat arvonlisäverottomia.

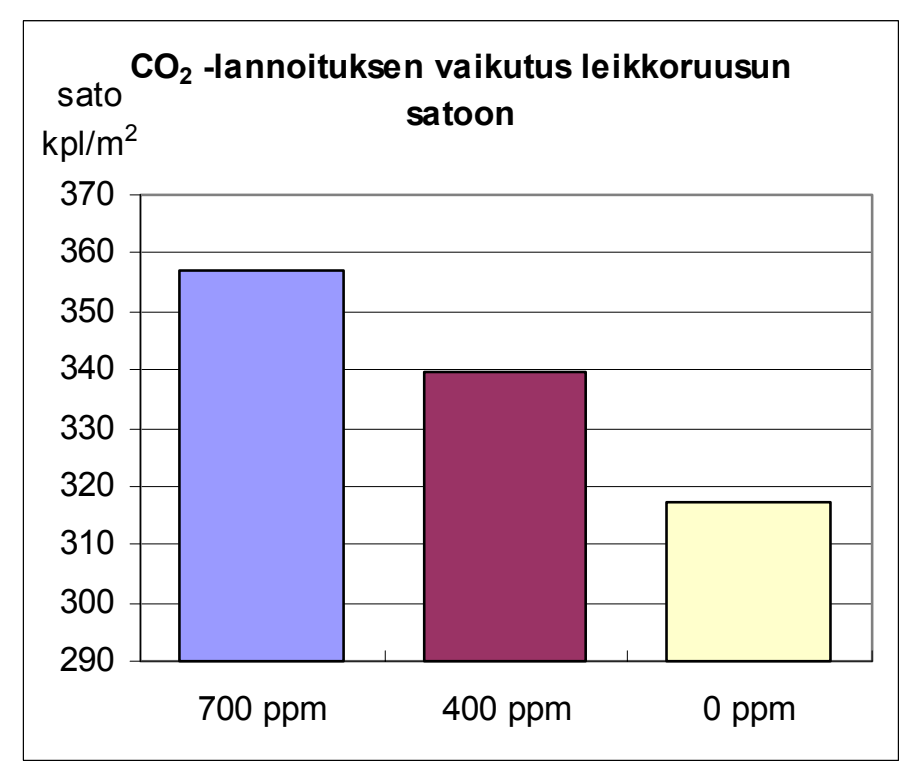

Kuva 1. Hiilidioksidilannoituksen vaikutus leikkoruusun satoon eri pitoisuuksilla 


\section{Tulokset}

Satotaso oli korkein suurimman hiilidioksidilannoituksen mallissa 1 ja pienin mallissa 3 josta lannoitus puuttui kokonaan. Suurimmalla hiilidioksidilisäyksellä (malli $1, \mathrm{CO}_{2} 700 \mathrm{ppm}$ ) viljelyn tuotantokustannus oli korkein, $114,3 € / \mathrm{m}^{2}$. Mallissa $2\left(\mathrm{CO}_{2} 400 \mathrm{ppm}\right)$ tuotantokustannus oli $110,9 € / \mathrm{m}^{2}$ ja mallissa $3(0 \mathrm{ppm}) 109,8$ $€ / \mathrm{m}^{2}$. Kustannusten erot aiheutuivat suurimmaksi osin eri satotasoista. Sadon lisäys vaikuttaa eniten työkustannukseen (sadonkorjuu, lajittelu ja kauppakunnostus), mutta myös kauppakunnostustarvikkeisiin sekä rahtikustannukseen. Eroja kustannuksiin aiheuttaa myös hiilidioksidilannoitus sekä pienessä määrin kasvinsuojelu.

Huolimatta korkeista kustannuksista myös viljelyn tuotot olivat korkeimmat mallissa 1 ja alhaisimmat mallissa 3. Tuottojen laskennassa on oletettu, että koko sato myydään painotettuun leikkoruusun keskihintaan, joka vuonna 2000 oli $32,12 \mathrm{snt} / \mathrm{kpl}$. Kasvihuonetuotannon tuki $\left(11,4 € / \mathrm{m}^{2}\right)$ on myös laskettu tuottoihin. Tuottojen ja kustannusten erotus kuvaa varsinaisen liiketoiminnan tulosta (liikevoitto/-tappio). Kaikissa malleissa viljelystä saatiin voittoa. Suurin voitto oli suurimman hiilidioksidilisäyksen mallissa, $11,8 € / \mathrm{m}^{2}$. Tuloksiin sisältyy korvaus viljelijäperheen tekemälle työlle. Mallissa 2 ( $400 \mathrm{ppm})$ tulos oli $9,4 €$ ja mallissa 3 (0 ppm) $3,4 € / \mathrm{m}^{2}$. Mallissa 2 hiilidioksidilisäyksen kustannus oli $0,7 € / \mathrm{m}^{2}$ säiliön vuokran kanssa laskettuna. Tällä saatiin kuitenkin 22 ruusun sadon lisäys ja 6,0 euroa parempi tulos neliömetriä kohden kuin mallissa 3, jossa $\mathrm{CO}_{2}$ - lannoitusta ei ollut lainkaan.

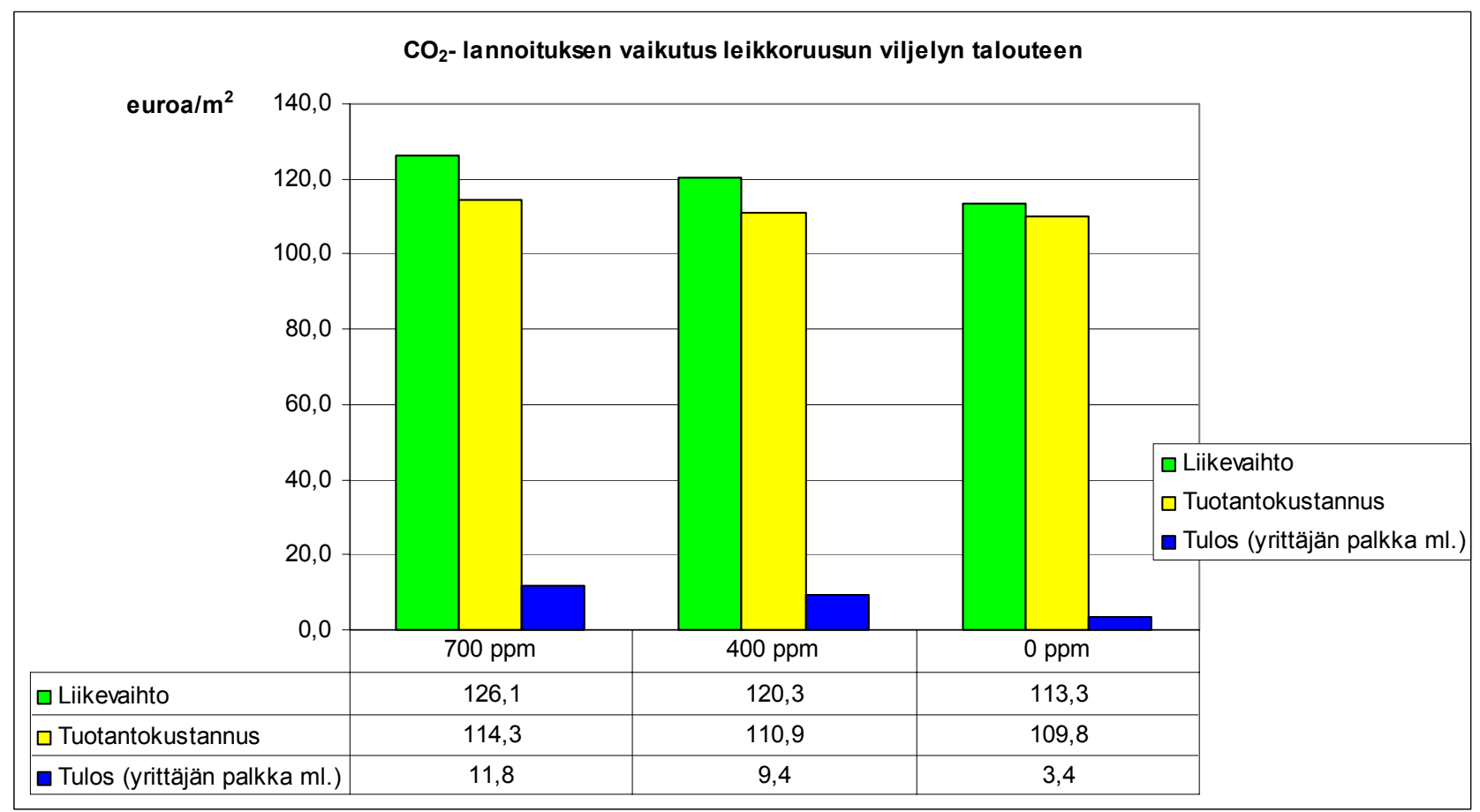

Kuva 2. Hiilidioksidilannoituksen vaikutus leikkoruusun viljelyn taloudelliseen tulokseen

\section{Tulosten tarkastelu}

Hiilidioksidilannoituksen käyttö lisää leikkoruusun satoa ja parantaa viljelyn kannattavuutta jo alhaisemmallakin pitoisuudella. Lajikkeiden välillä tosin on eroa, kaikilla lajikkeilla ei satotason lisäys ole yhtä suuri.

Tilamallitarkastelulla voidaan simuloida mahdollisimman tarkasti viljelykokeiden mukaista viljelytekniikka ja eri käsittelyjen vaikutuksia viljelyn taloudelliseen tulokseen. Laskelma on kuitenkin herkkä siinä käytettävien oletusten ja lähtöarvojen suhteen. Mallin ei siten voidakaan sanoa kuvaavan ruusun keskimääräistä tuotantokustannusta. Tilamalleilla ei myöskään voida huomioida yrittäjän tuotannollisia eikä markkinoihin liittyviä riskejä. 